\title{
BLACK MIRROR, ENHANCEMENT AND THE IMPOSSIBILITY OF FORGETTING
}

\section{Miša Đurković}

UDC 159.953.6:004

330.341.1:179

7.097:791.632-051Brooker, Ch.

https://doi.org/10.32701/dp.23.1.2

Original scientific paper

Received: 04.05.2021

Accepted: 14.09.2021

Abstract

Modern cognitive and experimental science is increasingly working to explore the meaning and importance of forgetting. Forgetting is one of the most important mental functions on an individual level, but also on a social and national level, since it enables healing, purifies the mind of difficult memories, prevents obsession with problems, and eliminates the possibility of psychosomatic illnesses.

The famous British TV series Black Mirror, which has become a symbol of the challenges that modern and futuristic technology brings to man, deals with the problems that arise due to the obsession of the gadget culture with abolishing forgetting through technological enhancement. Several episodes are based on gadgets that expand the potential of memory and make it constantly available to other subjects, in the way that data from a person's entire history become available. In a dialogue with Brooker's ideas, the author re-examines the problems spawned by this future society without forgetting, and searches for possible solutions.

KeYwords: Black Mirror, Charlie Brooker, enhancement, forgetting, memory

\section{Introduction}

The problem of memory, recollection, storing of facts, data and events has occupied Western philosophy and science since their inception. But in the last twenty years, philosophy, together with psychology, history and even

+ The article is a revised and extended version of the paper presented at the international symposium held in Zagreb on 20th November 2020, titled 'The Impact of Technology on Human Being and Its Self-understanding'.

* $\quad$ Miša Đurković, Ph.D., Institute of European Studies, Trg Nikole Pašića 11, 11000 Belgrade, Serbia.E-mail: mdjurkov@gmail.com

ORCID iD: https://orcid.org/0000-0003-4305-8184 
neurosciences, has begun to deal more and more with the issue of oblivion, that is, forgetting. What is forgetfulness; is it a lack, an absence of memory, its erasure, something contrary to memory and recollection, or a phenomenon in itself; what types of forgetting exist, can forgetting be intentional, why is there an art of memory (ars memoriae), but not the art of forgetting (ars oblivionalis), how are phenomena such as sleep, amnesia, dementia, Alzheimer's disease, or excessive memory disease (hyperthymesia), which Borges attributed to his hero Ireneo Funes in 1942, classified ... What are the cognitive consequences of externalizing memory, does it improve or reduce our capacities, can technology and pharmaceuticals help the normal functioning of memory and the dialectic of memory and forgetfulness, or will we become overwhelmed by data, whose quantity is constantly increasing ... Finally, what are the consequences of the world of computers, social networks, clouds, eternal memory, in which forgetting becomes technically impossible and data storage is the norm ... All these issues weigh heavily on us due to the obvious changes in the world and of the way people function in it, with increasing challenges and problems.

In this article, we will try to summarize the most important parts of the current discussion on the phenomenon of forgetting, with special emphasis on the problems that arise in the world of digitalization and social networks, where forgetting becomes impossible, and storing all possible data and universal data availability become the norm ${ }^{1}$. In considering this set of issues, we will rely on several episodes of the cult British series Black Mirror, the most relevant, stimulating attempt in modern popular culture to examine the dark sides of technological progress and digital gadget addiction.

\section{From the duty to remember to the right of forgetting}

When analyzing the phenomenon of forgetting, we must take into account the level, plane, and formation at which the process takes place. Are we talking about oblivion on an individual level, in a small community (e.g. a family) or in a large collective, such as a nation or a state? What is good for the individual might not necessarily be beneficial for the collective, whether small or large. And in this field, understandably, there are numerous dis-

1 This basic turn, which is the source of the problem we are dealing with in the article, Aleida Assmann defines in the following way: "Most of it is lost. Until recently, this oldest self-description of human memory applied to individuals, as well as to societies and cultures. Forgetting functioned automatically and imperceptibly, while special efforts were required to remember." (Assmann 2016, 218. Translation from German by the author). Now, however, preservation happens automatically, and we must fight for the right to oblivion and to forget things that concern us. 
putes. Namely, we used to believe that forgetting is something that is by definition bad, like deprivation, a lack (privatio) of matter, an undesirable emptiness (Assmann 2016, 12). Children with good memory are praised and applauded compared to children who show weaker memory abilities. Furthermore, historians have developed a phenomenon known as the culture of remembrance, which began with the struggle of the Jewish community after World War II to avoid forgetting the Holocaust. Avishai Margalit (2002) thus speaks of the "ethical responsibility to remember", which is the formulation that Assmann uses for the culture of remembering the Holocaust in Germany (ethischen Pflicht) (Assmann 2016, 11). Paul Ricoeur's significant work is also largely marked by this intention of thematizing remembering and its suppression. From the perspective of Eastern Europeans, who perceived the USSR as an occupying power, Kundera spoke about the "struggle of memory against oblivion" in his famous work called The Book of Laughter and Forgetting. Hirst and Yamashiro $(2018,76)$ summarize this classic approach by recalling the psychological perception of the problem: forgetfulness leads to psychological discomfort, and memory creates a healthy individual. So, for a long time, the Enlightenment's paradigm of accumulation of memory and knowledge was the valid norm on all levels, and the absence of memory was seen as a shortcoming.

This paradigm has been seriously re-examined over the past few decades $^{2}$, largely due to the spread of the Internet, digitization, social networks, but also due to the radical spread of nationalism and other types of division within communities and states. Rabelais's famous narrative about Gargantua and Pantagruel deals with the problem of Gargantua's saturation with the powerful scholastic knowledge that burdens his brain. The doctor prescribes him a medicine that will make him sneeze and consequently shed all unnecessary knowledge and facts, and finally open his mind up to clear and unfettered thoughts ${ }^{3}$. While four decades ago, in the real, analog world, there was an obsession with the need to preserve as much as possible, as described by the Serbian writer Danilo Kiš in the story "Encyclopedia of the Dead", today it seems that everyone is feeling the pressure of huge accumulation of information, and more and more people are suffering its consequences. It is as if we are taking advantage of new technological breakthroughs, while at the same time feeling more and more dependent on them, but we are also becoming increasingly aware of their dangers. ${ }^{4}$

2 In 2009, Ann Whitehead summed up this turn with a precise claim that the research of forgetting is perhaps a crucial aspect of the further research of memory (Assmann 2016, 13).

3 This example is given by Hirst and Yamashiro $(2018,76)$

4 We are also witnessing phenomena that incorporate opposite messages and attitudes towards memory and heritage. In 2020, we saw that under the influence of the Black Lives 
Meanwhile, the phenomenon that Borges prophetically described in fiction in 1942, has been registered, and was scientifically confirmed in 2006. Hyperthymesia has been described as a scientific phenomenon, but many would say that it is more of a disease than a gift ${ }^{5}$. It has been estimated that there are about 60 to 80 people in the world who have hyperthymesia, a condition that makes them remember in detail literally every day of their lives. A woman named Jill Price published her memoirs in 2008, in which she explained that she did not benefit from this condition. It bothered her primarily in emotional relationships because she could not erase and forget anything from the history of the relationship with her partner or with her relatives (Price and Davis 2008, 7) ${ }^{6}$.

Digitization, social networks and computers are creating a world in which hyperthymesia is becoming a mass, collective disease. Although humans remember and forget as they have always done, cloud storage is now there to memorize and record everything about us; our histories, nonsenses, emotions, defeats, humiliations, etc.

These problems are discussed by a significant number of authors, and here I would like to single out the monographs by Draaisma, Mayer-Schönberger and Kate Eichhorn. In 2015, the Dutch psychologist Draaisma published an important book dedicated to forgetting, that ranges from neurophysiology to popular culture, and explores the forms and mechanisms of forgetting, while using numerous examples. The book is actually an attempt to systematize various problems that are related to the process of forgetting and that we all face. At the end of the book, the author even gives a list of questions that we need to ask ourselves and thus continue the research.

The approach we are interested in was actually founded by the German thinker Viktor Mayer-Schönberger with his extremely stimulating, and multi-award-winning book from 2009, Delete, the virtue of forgetting in the digital age. Mayer-Schönberger, who in the meantime became Chancellor Merkel's advisor on digital policy, pointed to the issue of eliminating oblivion in the world of social networks and digitalization, and indicated what problems these innovations bring. He talks about the progress of digital memory and the impossibility of forgetting as a tendency of the changing world we

Matter movement, an avalanche of events was initiated, in which, on the one hand, honoring the memory of the victims of colonialism and slavery was demanded, and on the other hand, monuments, the most important memorials and symbols of history, were being destroyed and torn down.

5 The digital hyperthymesia of the world we live in today is increasingly seen as a curse instead of a blessing. See the excellent literary analysis of Borges' story in Laguna Mariscal and Martinez Sariego, 2010, entitled "When memory is condemnation".

6 Her brother and mother related how hard it was to live with someone who never forgets and never overcomes problems. See "Woman Who Can't Forgett Amazes Doctors”, https:// abcnews.go.com/Health/story?id=4813052\&page=1, Accessed May 18, 2021. 
live in. He offers the example of Stacy Snyder, who was denied a teaching degree after having posted a picture of herself on a social network (what later came to be known as the "Drunken Pirate" case, after the caption she had posted along with her photo). After his analysis, Mayer-Schönberger advocates for the right to be forgotten, and gives certain suggestions on how to reintroduce forgetting technologically and normatively. The Snapchat app was an attempt to create such a technological model: a social network that would enable the disappearance of uploaded content in the future.

Ten years later, a media professor from the New School for Social Research, Kate Eichhorn, with new experience and examples, applied Schönerberger's research to children and teenagers. Her book is called The End of Forgetting: Growing Up with Social Media (Eichhorn 2019). The author analyzes how minors suffer the consequences of social networks as their most frequent users, and how they have lost the privilege of anonymous adolescence, a period in which you should be able to do foolish things, experiment and do things that you will probably find embarrassing (or worse) in the future. According to the psychoanalyst Eric Ericsen, she speaks of the psychosocial moratorium as a right that adolescents had in almost all societies. In the digital age, however, nothing is erased; people are haunted by the demons of their former selves that can harm them in different ways, including causing mental health problems, costing them a job, or even their life. The book also provides a great overview of the history of selfie photography, tracking, i.e., tagging, and other phenomena that define modern-day communication and the eternal digital memory, in which information once sent, as a rule, never disappears, and cannot be forgotten.

The authors of the entry on memory in the Stanford Encyclopedia of Philosophy (Michaelian and Sutton 2017) point out that today the two most interesting debates in this field are on the subject of suppression of traumatic and unwanted memories and remembrance, and on the use of memory enhancement methods using pharmaceutical or other means. The latter includes the issue of the technological externalization of our memory, and opens up various dilemmas, such as the possibility of external intervention in our memory (like in Nolan's movie Inception). Let me add another issue to this list: the debate on the desirability or non-desirability of collective oblivion in larger communities, nations and states.

\section{The planes of forgetting}

Let's see how the thematization of forgetting takes place on different planes. First of all, there is a general debate about what forgetting is, that is, if there are different types of memory, as well as different types of forgetting. As early as 1932, in his famous book on memory, Bartlett challenged the old 
paradigm that sees memorization as the placing of information in our brain as in a large library or a computer, from where we extract what we need when we need it. Instead, he believes that memorization is always a reconstruction, a rebuilding of the context in which information or data occurs. From that perspective, forgetting would be a "failure to reconstruct an element of the past in a specific situation when memory takes place" (Hirst and Yamashiro 2018, 81). Human memory depends on the importance attached to information or data, so it is necessary to renew and register that meaning for reconstructions as well. Experiments have shown that the probability of forgetting a certain material increases by reducing its importance in communication in some way.

Hirst and Yamashiro also talk about the difference between the availability and accessibility of information as an important distinction for understanding the form of forgetting. Sometimes information is available, but we fail to access it, to reconstruct the context, the meaning in which it would adequately appear. This is the well-known phenomenon when we cannot remember something, e.g., an expression that is on the tip of our tongue: when we know that we know something, but we cannot remember it. Similarly, in the tenth book of his Confessions, St. Augustine distinguishes between partial forgetting, which includes the process of forgetting itself, and total forgetting, when nothing can be recovered or reconstructed (St. Augustinus, 197-207).

Finally, these two authors, who focused primarily on social and collective forms of forgetting, and who insist on functionality as the key framework for understanding the role of forgetting in society, bring us a stimulating taxonomy with a list of seven types of forgetting made by Connerton in 2008 (Hirst and Yamashiro 2018, 77). They talk about (1) forgetting as repression, erasure; (2) prescriptive forgetting (Spain after Franco); (3) forgetting in order to construct a new identity (forgetting of ancestors); (4) structural amnesia (suppression and oblivion of what bothers us from the past, like a father who was a criminal); (5) forgetting as the annulment of information; (6) planned obsolescence (strategy for introducing a new product on the market to replace the old one); (7) silence over humiliation (deleting and suppressing the unpleasant). ${ }^{7}$

Modern cognitive and experimental science is increasingly working to explore the meaning of forgetting. Forgetting is one of the most important mental functions on an individual level because it enables healing, purification of thoughts from difficult memories, it prevents obsession with problems, and eliminates the possibility of psychosomatic illnesses. Fur-

7 Assmann (2016, 30-68) offers her own, somewhat different taxonomy, primarily focused on the forms of collective forgetting. 
thermore, just like a computer with its memory cleared of redundant and unnecessary data, the brain's processor can process data better and faster, perform cognitive operations, connect laterally, and so on. ${ }^{8}$ We can all list numerous cases of events, unpleasant situations, and relationships that were very difficult for us at the time when they happened, and that we would be very happy to forget and banish from our memory. Some impressions are so strong that they trigger adrenaline and a strong vortex in the brain, so we cannot eliminate them naturally, but sometimes one has to reach for some kind of blockers, such as a chemical substance or an opiate that can stupefy a person and thus provide them with much-needed peace or sleep. ${ }^{9}$ As it is known, numerous cultures have developed such mechanisms for controlling thoughts and state of mind, from shamanism and meditation to prayer and hesychastic silence.

Hence, Draaisma speaks of the need and aspiration to develop a kind of art or a practice of forgetting, which would enable us to suppress and remove unpleasant impressions and thoughts, relieve unnecessary worries and make room for new impressions, events and relationships; in other words, which would allow us to restart, and give us relief from the excessive burden of the past.

In Christianity, repentance and confession have a deep therapeutic function: resolving and then suppressing what troubles a person. The torment and the sin that a person carries within themselves are released by sharing it with a trusted person, a priest, who consoles, teaches and resolves. The very moment of absolution and forgiveness has a profound therapeutic effect on the person who confesses. Of course, man continues to fight against sinful urges and memories, but he is aware that by repenting and confessing a significant part of the burden is released and forgiven, and that the way is open for him to start from the beginning. In the article "The End of Forgetting” (2011), Jeffrey Rosen reminds us that the Talmud had very strict provisions on the prohibition of gossip because in small communities memories can last for a long time, and every word spoken about others is written in the clouds. The Talmudic sages believed that God keeps a record of all our sins but that He can also erase it if the sinner begs forgiveness and apologizes to the person whom he has wronged. It is assumed that people can repent and

8 One school of thought believes that by relying on the externalization of data, our cognitive abilities also weaken, giving the example that we all used to know a dozen phone numbers by heart, and today we don't even know our own. Another school, however, believes that externalizing data can help in a way that creativity, thinking and thought operations are enhanced, and then that "software" is applied to data that is already on the Internet, in books, etc.

9 Depression and dark thoughts are often cited as causes of suicide. 
progress spiritually, rising above their past, so they should not be pushed back into it (Rosen 2011).

Then there is the level of small communities, the family being the most important among them. Contrary to fairytales, in which the story ends with the famous phrase that, after many adventures and temptations, the couple got married and lived happily ever after, in real life, the wedding actually marks the beginning of a dynamic marriage, which consists not only of beautiful moments between the spouses (and later between parents and children), but also of numerous problems, temptations, misunderstandings, anger, quarrels, and other situations that we would later like to forget and leave behind. Some of these issues are resolved over time, through conversation or throughout life, but others are not possible to overcome positively and permanently. Family members often have to learn to live with the traces of the past that burden them, so the art of forgetting and the repression of memories, that is, the will to forget, are actually very important for the survival of the small community. At the level of marital relationships, therefore, partners sometimes overcome crises through forgetfulness by trying to suppress previous issues, while building on what is valuable, what connects them and what leads them forward. Digging through marital history creates obsessions, frustrations, and can even lead to tragedies like the one described in Ibsen's play The Wild Duck.

At the level of collective memory, this new paradigm is based on the insight that Ernest Renan presented in his famous essay "What is a Nation" back in 1882. The functioning of a nation, he warned, depends not only on shared memory but also on the shared forgetting of certain unpleasant moments from the history or genealogy of the nation. For his native France, it was singularly important to suppress the study of the process of the formation of the French nation, which was largely done by forcibly removing regional differences, cultures, languages. During World War II, the Germans sought to revive Breton nationalism and other regionalist movements. A good example of the usefulness of the strategy of oblivion chosen by the national elite with the goal to save the state and the nation, is Spain after Franco ${ }^{10}$. Visiting the Belgrade Faculty of Political Sciences immediately after October 5, one of the authors of the Spanish constitution of 1978, Miguel Herrero y Rodríguez de Miñón, said that he was astonished by how much it was talked in the Balkans at the time about transitional justice, the need to face the past, etc. "If we had done that after Franco," he said, "the state would have fallen apart, and maybe we would still be waging civil war today," he concluded ${ }^{11}$. After Tito's death, Yugoslavia, as is well known, moved in the same direction. 
The Enlightenment attitude towards memory was built on the idea of tabula rasa. The revolution, the original social contract, and starting from the beginning were favorite metaphors at the time. Today, however, this paradigm seeks to dig as deep as possible, to force societies to face their history, the truth, the injustice, all that de facto divides them and makes them dysfunctional. It is as if quasi-Foucault's archeology is an inevitable method in every field, whose goal is to re-evaluate, annul all inherited values and interpretations of the framework of the society we live in, and to constantly bring all unpleasant things to light.

Hirst and Yamashiro remind us that memory is collectively conditioned, and that we remember and forget on the basis of the schemes that we internalize, according to which we register (or not), emphasize, or forget certain data, facts and connections. They highlight the primacy of functionality: the purpose of memory is not to represent the past as it really was, but to allow the past to persist in the present and perform three basic functions - to manage present and future thoughts and memories, to allow continuity of identity, and to develop and maintain social connections (Hirst and Yamashiro 2018, 82). The point is that the community, the nation, and its institutions have a priority position in defining the schemes, symbols, and frameworks of the paradigm through which we remember or forget. ${ }^{12}$ Based on that, the individual and the group forget selectively and collectively, hence the constant struggle to control the space through which these schemes are defined and spread through one society or community. As Ebbinghaus observed, the level of forgetfulness can increase or decrease depending on such social factors. Hence, these authors talk about the adaptive function of memory, but also of forgetting.

It is no coincidence that the politics of history and the politics of memory are some of the most important subjects of debate and dispute today both within states and between nations. Turkey imposes draconian punishments to ban the claim that the suffering of Armenians in 1915 was a genocide. ${ }^{13}$ In his latest book, Forward to the Past: Studies in the Politics of History in Poland, Ukraine, and Russia, Milan Subotić (2020) synthesized in a remarkable way the discussions on memory and oblivion in these three countries regarding some dramatic and controversial events, such as the pogrom of Jews in the town of Jedwabne in Poland in 1941, the so-called Holodomor

12 Because the individual functions within different communities (from the family and the working collective to the nation and the state) which have their own schemes, illusions are created about a greater individualization of memories and forgetfulness.

13 In 2017, the Turkish Parliament passed the bill banning the use of the term „Armenian Genocide“. See https://asbarez.com/165042/turkeys-parliament-bans-the-use-of-theterm-armenian-genocide/. Accessed May 20 2021. The article 301 of Criminal Law is also often used as a basis for prosecution. 
in Ukraine, and the Katyn Forest massacre, i.e., the occupation of Poland in alliance with Hitler in 1940 in Russia. These are great examples of states de facto striving to interpret, suppress, and even forget certain historical episodes that they consider harmful to the national self-esteem and to the image they try to project to their people. In this context, it is worth looking at Assmann's studies, such as her book Work on National Memory.

All of these debates can be traced to Nietzsche's polemic against Hegel and nineteenth-century historians. In the important work On the Advantage and Disadvantage of History for Life (Nietzsche 1874), presenting his critical attitude towards obsession with history (as opposed to the monumental and antiquarian approach, as he called them), Nietzsche claims that too much history hinders freedom, vitality, creation, and culture. The authors we consulted in this article regarding the current debates on oblivion, intuitively follow Nietzsche's position on the problem of the burden of memory and of the past, and try to get the subjects to move away from history on all these levels and move on to living and creating with as light a burden as possible on themselves and their new narratives and events. ${ }^{14}$

\section{Cases in Black Mirror}

The famous British TV series Black Mirror ${ }^{15}$, which has become a symbol for the challenges that modern and futuristic technology brings to man, deals with the problems that arise due to the obsession of the gadget culture with eliminating forgetting by technological enhancement. Several important episodes are based on gadgets and instruments that enable overall technological hyperthymesia, expand memory, and make it constantly available, not only to individuals, but to a whole range of other subjects, to whom data from all human history are available.

Like Facebook reminds us of beautiful moments without our consent, in Black Mirror, some less benevolent actors extract unpleasant, humiliating and compromising moments from people's history and use them to blackmail them or to enact endless punishment. In addition, such possibilities encourage some to endlessly dig through their own and others' histories, to reconstruct deceased people they miss from data found on social networks, to construct horror narratives for gamers based on their fears, or to preserve the complete consciousness of a deceased person on a hard drive, in their

This attitude does not necessarily imply rejecting tradition, on the contrary. It can mean the struggle for the freedom to choose or practice a certain tradition, a certain type of memory, a certain type of personal but also collective identity and self-perception against external pressures to either eliminate it or impose an unwanted narrative.

Brooker, C. and Jones, A. and Arnopp, J. 2018. https://www.imdb.com/title/tt2085059/. Accessed May 20, 2021. 
brain or in an AI egg. Let's look at a few examples in which Brooker, the creator of the series, deals with a future where digital memory removes the possibility of forgetting and forgiveness, and with the resulting consequences.

Debating the relationship between technology, gadgets and memory plays a very important role in the narratives that Brooker builds in the series. In the first season, the legendary "Grain" appears, a device around which the third episode, "The Entire History of You”, is built (it also appears in some later episodes with a rewinding mechanism). This is a kind of variation on the Wild Duck, but at the same time, it is a description of a dystopia that lurks in a world without forgetfulness, where everything is recorded through external memory and built into our brains, and people's whole lives, as well as the social, economic and political system, are developed on the obsessive mutual re-examination and checking of the past of individuals. The Grain is a device that is bought and installed behind the ears. As Liam rides in a taxi, we see an advertisement for a new-generation Grain with expanded memory, just like a memory card for a phone. The Grain has de facto become mandatory because, for example, at the airport, the security might request a "redo", i.e., ask a person to rewind their memory of that day or of the whole week if they seem suspicious. Along the way, in a dinner scene, we hear that half the people can have false memories.

The plot begins at a dinner party with a dozen people, when Liam notices a special relationship between his wife Ffion and a man named Jonas. Based on the rewinded memory, having the possibility of lip-reading in their recorded conversation, he concludes that the two of them were, or are, in a relationship, and that Ffion is hiding it from him. He then becomes obsessed with the past, and in a few tragic steps filled with suspicions, lies, and violence, he creates a humiliating situation, where he forces Ffion to rewind the memory of sex with Jonas in order to find out if they were using a condom because he suddenly suspects he is not their daughter's father. At the end of the episode, we see him destroyed, memory-addicted, rewinding the memories of his daughter and ex-wife, who appears to have left him. In the last scene, Liam symbolically tears out his Grain.

Brooker himself (Brooker and Jones and Arnopp 2018, 83) said that his intention here was to point out the phenomenon of the impossibility of forgetting in the world of the future and the problems that it would bring. The basic idea for the episode was people destroying themselves with their memories, by constantly repeating all their failures, uncomfortable situations, humiliations, and fears. ${ }^{16}$ Since everything would be covered and 
networked with cameras and microphones, people would constantly be exposed to surveillance, but also produce and send material endlessly, and every moment of their lives would be recorded somewhere.

However, cinemas would still try hard to ensure that no one recorded the movies played on the big screen, and thus would become place of refuge and privacy, where people go to talk, have sex, etc.

The first episode of the second season opens with the bizarre story "Be Right Back", which talks about the possibility of identity reconstruction after death, based on data, traces and posts that someone had left on social media. Brooker stated that he wanted to contrast this story with the mourning period in the real world, when family members and friends of the deceased store their photos in the attic so that they would not remind them of the past and of the pain that the person's passing had caused them (Brooker and Jones and Arnopp 2018, 99). In this narrative, Ash, a young man addicted to social networks, dies, leaving behind his pregnant wife, Martha. In deep pain, Marta accepts her friend's suggestion to sign up for a service that offers reconstructing Ash's identity using information from his social media profiles and online communications and placing it in a new AI software. A text from "Ash" arrives, and Martha begins to communicate over messages with this AI, hoping that it would help her overcome the pain and fill the void. Soon, their communication switches to phone conversations in order to enable the company to create a robot in the form of Ash. Although the robot is physically identical to Ash, and she even makes love to him, Martha realizes that this surrogate cannot replace the truly unrepeatable human being she loved. In the end, she puts him (it?) in the attic and allows her daughter to go and see him once a year, on her birthday. ${ }^{17}$

Several episodes of Black Mirror explore the possibility of manipulating one's consciousness. A gadget called egg is introduced, a chip on which somebody's entire consciousness can be stored. The episode "San Junipero" discusses this idea of transferring one's consciousness to a hard disk, surviving in an eternal virtual reality. But certainly, the most memorable episode that deals with the problems of digital memory is "Shut Up and Dance", broadcast in October 2016.

The main character, Kenny, is a young man who installs an anti-malware program on his computer and, with it, a Trojan virus, through which exploring artificially created oblivion. Victoria, a participant in a crime against a child, is condemned to be the main star in a reality park, that is a form of a monstrous prison for her. Every night, her memory is chemically erased, and every morning, like in the movie Day of the Groundhog, hell starts all over again; she is haunted by unknown people all day long, while thousands of park visitors silently record and keep track of what is happening with their phones. 
unknown people begin to monitor his behavior on the computer. He soon receives a blackmail email, threatening to send a video of him masturbating to pornography to everyone on his contact list. At least five more characters in the same situation appear in the episode, and perform various unpleasant, compromising and sick tasks in the hope that they will earn the forgiveness of the unknown hacker, so that he wouldn't expose their compromising behavior on the Internet. But the hacker takes them deeper and deeper into ruin. In the final scene, after having robbed a bank, Kenny and one of the other blackmailed men have to fight to the death while a drone films everything. Only then do we learn that they both "enjoyed" child pornography. Of course, the hacker spared no one, and regardless of their efforts, all the compromising material was exposed.

Although the episode takes the narrative to the extreme, the fundamental problem of recording everything we do in the digital world is captured and illustrated very well. We have already learned from Eric Snowden that the NSA, internet corporations, other services, and even smaller companies and individuals can monitor, register and record all our behavior on the Internet, including nonsensical, foolish things we might be ashamed of later, intimate relationships, and other compromising material. Let's take the phenomenon of sexting, which has already hurt hundreds of thousands of people. Private erotic messages, selfies or videos that people sent to each other online have ended up on porn servers, Facebook pages, or even mainstream web portals, released by a hacker, or after having their phone lost, or thanks to the so-called revenge pornography, when a former partner discloses such material as an act of vengeance. Just like poor Raza, known as Star Wars Kid, who is still laughed at today by millions of people because of the videotape of him imitating a Jedi (more precisely Darth Maul) in a lightsaber fight, many people have been exposed to cyberbullying, blackmail, ridicule, and other forms of humiliation because of compromising material found on the Internet and social networks, released against they will. Therefore, the question arises as to what to do in a world where there is no more forgetting and, as the founder of Facebook said, privacy is no longer the social norm. ${ }^{18}$ The last part of the text will try to look at the options available to us.

\section{Revitalization of Forgetting}

Eichhorn concludes her book with a synthesis of the problems we face: "Forgetting, as we have seen in this book, is not a completely negative phenom-

See https://archive.nytimes.com/www.nytimes.com/external/readwriteweb/2010/01/10/10 readwriteweb-facebooks-zuckerberg-says-the-age-of-privac-82963.html, Accessed May 202021. 
enon; sometimes it's really a necessity. Despite its bad reputation, forgetting has a certain function. Forgetting can help someone take a risk, explore new identities, accept new ideas; can help someone grow up. Forgetting can act as a handy tool to overcome something we are ashamed of, or as a cure for more serious trauma. Forgetting and being forgotten in this respect is synonymous with freedom ... Precisely because forgetting and freedom are connected, the end of forgetting has such great consequences, especially for young people.” (Eichhorn 2019, 143).

However, primarily because of the interests of companies, but also other interested parties, such as security services, the world strives to constantly expand memory, store as much data as possible and prevent oblivion. Ten years ago, at the end of his book, Mayer-Schönberger begins to explore the mechanisms by which oblivion could be re-enabled and which would allow people to get rid of the demons of the past that haunt them in the digital world. Exploring the possible options for dealing with this problem, he lists six responses. He starts with digital abstinence - refraining from sharing personal information. Then follows the legal approach, where the author mentions the lawyers who have begun to define various forms of the right to privacy, forgetting and erasure, that cover reputation, security, etc. Next is the so-called digital rights management, which enables individuals to manage everything that applies to them in the digital world according to the intellectual property model, including requests for deleting information.

While these three responses deal with the possibilities of control and prohibition, the next three proposals go in the direction of adapting to the new circumstances. The first approach is cognitive adjustment, according to which young people, but others too, should learn to deal with these new problems, be careful about what they are doing, and be ready for the consequences that global Internet usage entails.

The fifth method is information ecology. It is about determining how long can information be stored in digital memory (just like a criminal record is sometimes deleted so that one could move on unburdened by their past wrongdoings). Personal information should be deleted when the purpose for which it was obtained is fulfilled; we need to clear the digital space of unnecessary information (just like we have to delete our emails sometimes because the memory capacity allocated to us becomes full over time). The last approach, which he calls perfect contextualization, goes to the other extreme: one should accept that everything remains remembered and stored without exceptions. It is supposed that no one would be endangered because everything would be transparent. If everyone could know everything about everyone, then there would be no asymmetric control, and we would instead have horizontal networking. 
Although he believes that each of these approaches can bring something beneficial, Mayer-Schönberger advocates for a new technical solution that, according to him, would make things much easier: he proposes introducing the option of choosing an expiration date for everything that an individual uploads to the Internet. So, for example, when posting a tweet or creating a post on Facebook, each user would fill in the duration of the post and the time when it would have to be deleted. ${ }^{19}$

Ten years later, Eichhorn showed quite well why this model cannot solve problems. Namely, there are numerous possibilities for something that is present on the Internet to be recorded and saved in another format even when the author takes it down or deletes it. We all know of many cases where tweets, posts or images were removed by the original author due to various reasons (threats, shame, potential legal problems, etc.), and later their recordings or screenshots resurfaced. However, mention is made of research involving developing a software that could automatically destroy all forms of unwanted information, whether stored somewhere in a private archive or available online. But that is not realistic yet, and the question is how efficient it would really be, and whether someone would create a stronger software solution to counter such a process.

This leads us to another interesting subject: the business niche that has emerged in the meantime. There are plenty of people searching for a way to remove and hide evidence of their former blunders lying in the digital space. So, the fact that the number of such people is increasing to millions has created a new market for digital forensics. Just as companies hire specialized HR firms to search for everything that can be found about a potential employee on the Internet, so too can companies, as well as individuals, hire firms that offer this kind of forensics, combining technical and legal aspects, and enable the destruction of erotic images, recordings, politically incorrect compromising materials, and similar things - hence all that the characters in "Shut Up and Dance" did at the bidding of their blackmailer. In Serbia, this forensic service costs around 500 euros. Market demand encourages the development of this industry, as well as training employees, both in technical and legal field. Therefore, some progress is being made in the creation of mechanisms for implementing digital oblivion.

The most interesting development is happening in the field of legal regulations. Gone are the days when the Internet was thought of as a nomadic realm of freedom without borders, or a chance to restore direct democracy. ${ }^{20}$ The dark web has become a sanctuary for the most monstrous creations of the human mind, although various forms of pornography, games, digital 
gambling, brutality, pedophilia and other human pathologies can be found even in the publicly available digital space through regular search engines. For this reason, the demands for the regulation of the Internet and the digital sphere are growing. The defense of the right to oblivion has become the subject of expert analyses and practical proposals, but also of certain regulations that have been adopted and started being applied in the meantime.

In 2011, Jeffrey Rosen also tried to capture and list the tendencies in the fight for the possibility of forgetting on the Internet. Alex Türk, President of the French Data Protection Authority, even proposed the introduction of the constitutional right to be forgotten. Two Argentinian writers, Tortolini and Quagliano, have launched a campaign to "reinvent forgetting on the Internet". The EU then launched the "Think B4U" Post campaign, educating young people on the possibilities of prevention. The goal of all this, as Rosen has stated, is to increase the ability to control how we present ourselves on the Internet: "the ability to reinvent ourselves, to escape our pasts and to improve the selves that we present to the world" (Rosen 2011).

It is noticeable that the proposed methods are mostly either legal or technical. Among the legal, he mentions the following proposals: introducing a legal right to be forgotten, i.e., the option for each person to remove anything they had ever posted (which is technically difficult to fully implement); then, banning companies from investigating the private profiles of people for the purposes of job interviews (proposed by the German Data Protection Commissioner Schaar); enabling individuals to select which version of an event or data they want to see displayed at the top of the search results when searching a browser. There have been many cases of private lawsuits against search engines in Argentina aiming at banning the use of the plaintiffs' data or posts. All in all, it turns out that legal protection cannot offer much, at least not yet, so Rosen turns to the issue of technical prevention. In the meantime, the European Union took the first serious step in this direction and adopted the General Data Protection Regulation, which came into force in 2018, and its primary aim is to protect the control of individuals over their personal data, including the retention of personal data.

Rosen analyzed how Internet companies began to follow Mayer-Schönberger's recommendations to clear their servers and to build this option into their setup protocols, allowing data to disappear after a certain period, especially when it comes to private communications. For example, the TigerText application allows the sender to set the period after which the data will disappear from the server, but also from the phones of those who received it. Recently, the popular Signal has also introduced this option. The author also highlighted the development of a new technology called Vanish, as another step in the direction of data protection, which offers the possibility of data encryption, and incorporates a protocol for self-destruction of data 
after a certain time everywhere it was downloaded. However, that is still completely impossible.

\section{Conclusion}

To conclude, the abolition of oblivion and of the erasure of data have been recognized as major problems. Some researchers and practitioners want to combat this problem by legal and ethical means, education, and especially technological innovations and controls. Others, however, believe that this is a futile task and that we should simply get used to this new world in which there is no forgetting and where companies encourage us to expose ourselves give as much information as possible. Therefore, we need to learn new types of empathy, find new rules for self-definition and self-confidence, whatever others might say about us, and find new ways to forgive "digital traces that will follow each of us forever.” (Rosen 2011).

This second version really looks like a nightmare, as we have seen in "The Entire History of You": a world without forgetting would create a psycho-digital hell. Therefore, we can but work as much as possible to control and prevent damage and to reaffirm and promote the right to be forgotten, i.e. the right to oblivion, as one of the most important human rights in the world of advanced technology.

\section{References}

Assmann, Aleida. 2016. Formen des Vorgessens. Göttingen: Wallstein Verlag.

Brooker, Charlie, Annabel Jones, and Jason Arnopp. 2018. Inside Black Mirror. Crown Archetype.

Connerton, Paul. 2008. "Seven Types of Forgetting." Memory Studies 1 (1): 60-71.

Cook, Gareth. 2015. "The Book of Forgetting, interview with Douwe Draaisma." Scientific American. May 12. Accessed April 13, 2021. https://www.scientificamerican.com/article/the-book-of-forgetting/.

Draaisma, Douwe. 2015. Forgetting: Myths, Perils and Compensations. Yale: Yale University Press.

Eichhorn, Kate. 2019. The End of Forgetting: Growing Up with Social Media. Cambridge: Harvard University Press.

Hirst, William, and Jeremy Yamashiro. 2018. "Social Aspects of Forgetting." In Collaborative Remembering: Theories, Research, and Applications, edited by Michelle L. Meade, Celia B. Harris, Penny Van Bergen, John Sutton, and Amanda J. Barnier, 76-99. Oxford: Oxford University Press.

Jones, Steven. ed. 1997. Virtual Culture: Identity and Communication in Cybersociety. SAGE Publications Ltd. 
Kourken, Michaelian, and John Sutton. 2017. "Memory.” In The Stanford Encyclopedia of Philosophy. (Summer 2017 Edition). Edited by Edward N. Zalta. Accessed March 16, 2021. https://plato.stanford.edu/archives/sum2017/entries/memory/.

Laguna Mariscal, Gabriel, and Mónica Martínez Sariego. 2010. "Cuando la memoria es una condena: analisis narratologico de Funes el Memorioso de Borges.” Philologica Canariensia 16-17: 85-110.

Margalit, Avishai. 2002. Ethics of Memory. Cambridge: Harvard University Press.

Mayer-Schönberger, Viktor. 2009. Delete: Virtue of Forgetting in the Digital Age. Princeton: Princeton University Press.

Nietzsche, Friedrich. 1980. On the Advantage and Disadvantage of History for Life. Hackett Publishing Company.

Price, Jill, and Bart Davis. 2008. The Woman Who Can't Forget: The Extraordinary Story of Living with the Most Remarkable Memory Known to Science-A Memoir. Free Press.

Renan, Ernest. 1882. “Qu'est-ce qu’une nation? Conférence faite en Sorbonne, le 11 mars 1882.” Accessed January 16, 2021. https://archive.org/details/questcequunenat00renagoog.

Ricoeur, Paul. 2004. Memory, History, Forgetting. Chicago: The University of Chicago Press.

Rosen, Jeffrey. 2011. “The End of Forgetting.” La Clé des Langues. Lyon: ENS de LYON/DGESCO (ISSN 2107-7029), September 2011. Accessed October 28, 2020. http://cle.ens-lyon.fr/anglais/civilisation/les-dossiers-transversaux/nouvellestechnologies/the-end-of-forgetting.

St. Augustinus. n.d. Confessions. New York, Garden City: International Collectors Library. https://ia800301.us.archive.org/1/items/confessionsofsta00augu/confessionsofsta00augu.pdf.

Subotić, Milan. 2020. Napred u prošlost: studije o politici istorije u Poljskoj, Ukrajini i Rusiji. Beograd: Fabrika knjiga. 
Sažetak

CRNO ZRCALO, NAPREDAK I NEMOGUĆNOST ZABORAVLJANJA

MIŠA ĐURKOVIĆ

Moderna kognitivna i eksperimentalna znanost sve više se bavi istraživanjem značenja i važnosti zaboravljanja. Zaboravljanje je jedna od najvažnijih mentalnih funkcija na individualnoj, ali i na društvenoj i nacionalnoj razini, budući da omogućuje iscjeljivanje uma i brisanje neugodnih sjećanja, sprječava opsesivno razmišljanje o problemima i otklanja mogućnost pojave psihosomatskih bolesti.

Poznata britanska serija Crno zrcalo, koja je postala simbol za izazove koje moderna i futuristička tehnologija donosi čovjeku, bavi se problemima koji nastaju zbog opsjednutosti kulture gadgeta da se tehnološkim napretkom potpuno onemogući zaboravljanje. Nekoliko epizoda serije temelji se na gadgetima koji proširuju potencijal ljudskog pamćenja te ga čine dostupnim drugima, a time podatci o čitavoj nečijoj prošlosti postaju dostupni. Razmišljajući o Brookerovim idejama, autor razmatra probleme koje bi iznjedrilo takvo buduće društvo lišeno zaborava i traži moguća rješenja.

KLJUČNE RIJEČI: Crno zrcalo, Charlie Brooker, napredak, zaboravljanje, pamćenje

* Dr. sc. Miša Đurković, znanstveni savjetnik, Institut za europske studije, Trg Nikole Pašića 11, 11000 Beograd, Srbija. E-adresa: mdjurkov@gmail.com ORCID iD: https://orcid.org/0000-0003-4305-8184 